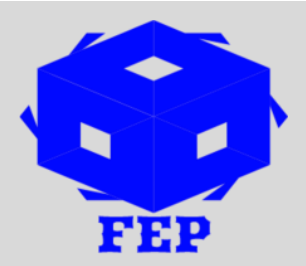

\title{
GOVERNMENT SPENDING ON EDUCATION, HEALTH, AND MINIMUM WAGES AS PREDICTORS OF HUMAN DEVELOPMENT INDEX: STUDY OF SELECTED PROVINCES OF INDONESIA
}

\author{
Pratomo Widodo ${ }^{1}$ \\ ${ }^{1}$ Gadjah Mada University, Indonesia \\ Lalu Ari Irawan ${ }^{2}$ \\ ${ }^{2}$ Gadjah Mada University, Indonesia \\ Ikmi Nur Oktavianti ${ }^{3}$ \\ ${ }^{3}$ Sebelas Maret University, Indonesia \\ Larasati Anisa ${ }^{4}$ \\ ${ }^{4}$ Pertamina University, Indonesia
}

*Corresponding Author: Pratomo Widodo

Article Received: 07-06-19

Accepted: 30-09-19

Published: 25-10-19

Licensing Details: Author retains the right of this article. The article is distributed under the terms of the

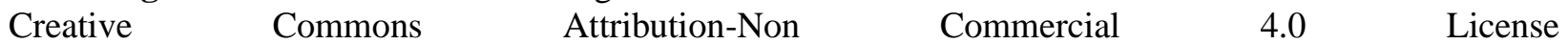
(http://www.creativecommons.org/licences/by-nc/4.0/) which permits non-commercial use, reproduction and distribution of the work without further permission provided the original work is attributed as specified on the Journal open access page.

\begin{abstract}
The study objective was to test the influence of three factors namely government spending on education, health, and minimum wages on human development index in five selected provinces of Indonesia. The method of analysis is the Panel-data based analysis covering the time period of 2007 to 2016. The study is focused towards five selected provinces in Indonesia including Bangka Belitung, Lampung, Bengkulu, South Sumatra, and Jambi. The results show that government spending on education and health bring positive but insignificant effects on human development index; whereas, minimum wages turned out to be positive and significantly influencing human development index. Overall the HDI average is not much different and there is no discrepancy between provinces in Southern Sumatra from the range of 68 percent to 70 percent. However, of the five provinces in Southern Sumatra, there are two provinces with higher HDI figures than the others, namely Jambi Province and Bangka Belitung Province.
\end{abstract}


Keywords: Government Spending, Expenditure, Education, Health, Minimum Wages, HDI

\section{INTRODUCTION}

The concept of human development is highly important as it indicate the positive growth in the social, economic, cultural, political, and environmental fields. The main focus of the human development is to provide human resource opportunity to grow and enjoy productive, healthy, and longevity-based life (BPS, 2015).

The idea of human development index (HDI) introduced by United Nations Development Program (UNDP) back in year 1990. The process of calculating HDI in Indonesia started in year 1996. Initially, the calculation was 3 years based but now it changed to annual basis. It is calculated by the Ministry of finance while calculating the General Allocation Fund. The key indicators for making this calculation include life expectancy at birth, schooling length expectations and average, and per capital expenditure which represent decent standard of living (BPS, 2015).

Fiscal policy instruments are used to improve the HDI in Indonesia by setting budget allocation for such factors which contribute in human development. In reality, different government level such as local government may have their own policies for human resource development. The indicators of these policies can be the health and education sector budgets.

Such conditions become a polemic which raises the debate about the role of the government that has not been maximized in the welfare of society through the application of HDI policies (Mahulauw, Santosa, Mahardika, 2016).

The UNDP observed that HDI in Indonesia is increasing during the last 25 years time period based on the calculations of per capital income, education, and health. Its HDI remains 113 out of 188 countries with the highest rate of increase within Asia Pacific region. The advancement of Indonesia's HDI of 0.712 and 0.66 for women was driven by several factors, namely an increase in the average length of schooling up to 4,6 year; increase in per capita income by $135.4 \%$, an increase in life expectancy to 5-8 years between 1990-2015. Despite good indicators by HDI index, the UNDP warned that these measures are only indicators and do not show the actual picture of reality which is far more complex. In Indonesia there are 140 million people living at a cost of less than Rp 20 thousand per day and 19.4 million people suffer from malnutrition. While in the health sector, two million children under the age of one year have not received complete immunizations and the maternal mortality rate is 305 deaths per 100 thousand live births (Newswire, 2017). These indicators show poor condition of the human development in terms of education, health, and employment.

The HDI consist of three indicators. Healthy life and long life is the first indicator and is based on government spending on health. The education indicator is based on government spending on education. Decent living standard is the third indicator and is based on purchasing power or per capital income. In present study, the focus is utilizing the provincial minimum wage as indicator 
of decent living standard. The methodology employed is the panel data analysis technique and focuses on selected five provinces including Bangka Belitung, Bengkulu, Jambi, Lampung, and Southern Sumatara.

\section{LITERATURE REVIEW}

Setyowati and Suparwati (2012) made investigation about PAD and HDI. The study concluded that PAD is indicator of HDI. Furthermore, the DAU was found insignificant influence on HDI. Pramissella (2015) conducted study about 'Provincial Minimum Wage' along with service good expenditures influence on HDI in Lampung province. It showed that factors including inflation, development of regional minimum wages, and gross regional domestic product influence HDI in Aceh province.

Forcael, Gonzalez, Orozco, Opazo, and Vargas (2016) conducted study about HDI for three dimensions including health, education, and income. The findings states that the increase in construction industry is positively associated with the HDI but not the income dimension.

Edeme, Nkalu, and Ifelunini (2017) conducted study about HDI. The results indicate that government spending on different heads including health, agriculture, education, water resources, and rural development bring positive influence on HDI. Furthermore, the study showed that housing and environmental protection and energy expenditure bring negative impact on HDI.

MS and Sudirman (2017) conducted study about HDI factors in Jambi province in Indonesia. The results showed that government spending is influencing the HDI in this region. Furthermore, the study showed that government spending on health and education bring positive improvement on HDI in this region.

Bahtera, Muhammad, and Jamal (2018) conducted another study about HDI factors. Their finding indicate that government allocation for urban education budget bring positive influence on HDI especially the Pemekaran district of Indonesia.

Overall, the literature review indicate that government budget allocation especially in the education and health field along with infrastructure improvement projects leads to the HDI in the Indonesian provinces.

\section{RESEARCH METHODOLOGY}

The study is based on conducting influence of government spending on education, health, and minimum wages set on human development index in the Indonesian selected provinces. The data analysis is based on Panel data with period of 2007 to 2016. We developed the following equation;

$Y_{i t}=\beta_{0}+\beta_{1} X 1_{i t}+\beta_{2} X 2_{i t}+\beta_{3} X 3_{i t}+e_{i t}$

Where $\mathrm{Y}$ is the Human Development Index (Percent), $\beta 0$ is the Constant, $\mathrm{X} 1$ is the Government Expenditure in Education (Rupiah), X2 is the Public Expenditure in Health Sector (Rupiah), X3 
is the Minimum Wage (Rupiah), $\beta 1,2,3$ is the Regression Coefficient Each Variable, $i$ is Cross Section (Data Panel: 1 = Jambi Province, 2 = South Sumatra Province, 3 = Bengkulu Province, 4 = Lampung Provinnsi, 5 = Bangka Belitung Province), $\mathrm{t}$ is Time Series (2007-2016), Eit is Error Term (Error cross section term and error term time series).

\section{ANALYSIS RESULTS AND DISCUSSION}

\section{Panel Data Regression Analysis}

For best model selection, three tests including Lagrange Multiplier test, Hausman test, and Chow test are utilized.

Table 1

Model Testing Results

\begin{tabular}{lcc}
\hline Pengujian Model & Nilai Statistik & Probabilitas \\
\hline Uji Chow & 5,755559 & 0,1537 \\
Uji Hausman & 5,731537 & 0,1301 \\
\hline
\end{tabular}

Source: Data Processed, 2018

The results were contradictory between the Chow test and the Hausman test so we used the LM test which shows that the Random Effect Model is the suitable model for this study.

Table 2

Random Effect Model

Dependent Variable: IPM?

Method: Pooled EGLS (Two-way random effects)

Sample: 20072016

Included observations: 10

Cross-sections included: 5

Total pool (balanced) observations: 50

\begin{tabular}{crrrl}
\hline Variable & Coefficient & Std. Error & t-Statistic & Prob. \\
\hline C & 68.53505 & 1.133585 & 63.05038 & 0.0000 \\
PENDIDIKAN? & 0.000183 & 0.000168 & 1.080388 & 0.3856 \\
KESEHATAN? & 0.000338 & 0.000583 & -0.683635 & 0.5856 \\
UPAH_MINIMUM? & 0.001156 & 0.000506 & 3.885855 & 0.0058 \\
\hline
\end{tabular}

Random Effects (Cross)

JAMBI-C $\quad 0.513556$

_SUMSEL-C $\quad-0.180536$

_BENGKULU_C $\quad 0.356508$

_LAMPUNG-C $\quad-1.558555$

_BABEL-C 0.858156

Source : Data Processed, 2018

Random effect model regression equation as follows:

$$
\mathrm{HDI}=68.53+0.000183 \mathrm{PDK}+0.00033 \mathrm{KES}+0.001156 \mathrm{UM}
$$

The constant value is 68.53 shows that in case of zero government expenditure on health and education and with zero minimum wage, the HDI will still be 68.53. the coefficient for education 
indicate that one unit increase in government expenditure on education bring $.02 \%$ increase in HDI. The coefficient of government expenditure in health field shows that one unit increase in government spending on health bring almost $.03 \%$ increase in HDI. The minimum wage regression coefficient indicate that every one unit increase in minimum wage bring .12 increase in HDI

\section{Individual Analysis}

Table-3

\begin{tabular}{lccc}
\multicolumn{4}{c}{ Interspective Value of Each Province } \\
\hline \multicolumn{1}{c}{ Provinsi } & Coefficient & C & Nilai Intersep \\
\hline Jambi & 0.513455 & 58.7351 & 70.247525 \\
Sumatera Selatan & -0.180535 & 58.7351 & 58.544534 \\
Bengkulu & 0.255508 & 58.7351 & 58.881578 \\
Lampung & -1.457575 & 58.7351 & 57.275485 \\
Bangka Belitung & 0.778145 & 58.7351 & 70.514215 \\
\hline \multicolumn{4}{c}{ Source: Processed }
\end{tabular}

Source: Processed data, 2018

The individual province analysis is provided above. Results states that the highest intercept is 70.51 corresponding with Bangka Belitung Province means that minimum wage influence on HDI is greatest in this province. The second best province is the Jambi province with beta intercept of 70.24. The Bengkulu remains the third with intercept of 58.88; Sumatara Selatan remains the fourth with beta intercept of 58.54; and the Lampung remains at the end of the list with intercept of 57.27 .

\section{Simultaneous Significance Test (Test Statistics F)}

\begin{tabular}{llll} 
Table 4 & & & \\
Results of Weighted Statistics & Model Random Effect & \\
\hline R-squared & 0.230094 & Mean dependent var & 2.515771 \\
Adjusted R-squared & 0.126622 & S.D. dependent var & 0.271725 \\
S.E. of regression & 0.263285 & Sum squared resid & 3.177570 \\
F-statistic & 4.568007 & Durbin-Watson stat & 0.705014 \\
Prob(F-statistic) & 0.026375 & & \\
\hline
\end{tabular}

Source: Processed data, 2018

The Rsquare shows that these three factors explains $23 \%$ variation in HDI. The Fstatistics indicate that model is fit and significant $($ Fstat $=4.56 \mathrm{P}<.05)$.

\section{Effect of Government Expenditure on Education and Health and Minimum Wages on the Human Development Index}

The results indicate that among the three independent variables, government spending on education and health do not bring as much significant as the minimum wage in the human development index. Previous studies such as Muliza and Seftarita (2017) also found similar 
results. Based on data on minimum wage growth in Jambi Province, South Sumatra Province, Bengkulu Province, Lampung Province and Bangka Belitung Province experience growth in each year, in line with the Human Development Index which also experiences growth in each year. This is evidenced by the results of research which states that there is a significant positive effect of the minimum wage on the human development index in southern Sumatra. That is, if the minimum wage in Southern Sumatra increases then it will increase the human development index in Southern Sumatra. The increase in minimum wages will increase the need for decent living so that the standard of living is also increasing. As a result of the increase in the minimum wage received, the purchasing power of the people has increased so that it has a positive impact on the human development index in southern Sumatra. We can use the natural wage theory to explain these results since increasing minimum wages can enhance the people purchasing power which improve the living style of poor and economically marginalized people.

\section{CONCLUSION}

Our conclusion is that the minimum wages is the most important variable bringing influence on human development index whereas, education and health related spending found to be producing positive but insignificant influence on the human development index.

\section{References}

Bahtera, M., Muhammad, S., \& Jamal, A. (2018). Panel Analysis on the Effect of Government Expenditure on Education and Health Sector against Poverty Numbers in Aceh 20102015. International Journal of Scientific Research and Management, 6(1), 40-51.

BPS. (2015). Indeks Pembangunan Manusia. Badan Pusat Statistik Provinsi Sumatera Selatan.

Edeme, R. K., Nkalu, C. N., \& Ifelunini, I. A. (2017). Distributional Impact of Public Expenditure On Human Development In Nigeria. International Journal of Social Economics, 44(12).

Forcael, E., González, V., Orozco, F., Opazo, A., \& Vargas, S. (2016). Towards a methodology for assessing the Human Development Index in the Chilean construction industry. Obras $Y$ Proyectos.

Halili, S. H., \& Zainuddin, Z. (2015). Flipping the classroom: What we know and what we don't. The Online Journal of Distance Education and e Learning, 3(1), 28-35.

Lugastoro, D. P., \& Ananda, C. F. (2013). Analisis Pengaruh PAD dan Dana Perimbangan terhadap Indeks Pembangunan Manusia Kabupaten. Kota di Jawa Timur.

Mahulauw, A. K., Santosa, D. B., \& Mahardika, P. (2016). Pengaruh Pengeluaran Kesehatan dan Pendidikan Serta infrastruktur Terhadap Indeks Pembangunan Manusia di Provinsi Maluku. Jurnal Ekonomi Pembangunan, 16.

MS, M. Z., \& Sudirman. (2017). The Effect of Government Expenditures in Education and Health against Human Development Index in Jambi Province. The International Journal of Social Sciences and Humanities Invention, 4(8), 38233829. 
Newswire. (2017). UNDP: Indeks Pembangunan Manusia Naik Pesat. Retrieved from http://kabar24.bisnis.com

Pramissella, R. F. (2015). Pengaruh Upah Minimum Provinsi dan Alokasi Belanja Pemerintah Terhadap Indeks Pembangunan Manusia Provinsi Lampung. Retrieved from http://feb.unila.ac.id

Putra, P. G. M., \& Ulupui, I. G. K. A. (2015). Pendapatan Asli Daerah, Dana Alokasi Umum, Dana Alokasi Khusus, untuk Meningkatkan Indeks Pembangunan Manusia. E-Jurnal Akuntansi, 863877.

Setyowati, L., \& Suparwati, Y. K. (2012). Pengaruh Pertumbuhan Ekonomi, Dana Alokasi Umum, Dana Alokasi Khusus dan Pendapatan Asli Daerah terhadap Indeks Pembangunan Manusia dengan Pengalokasian Anggaran Belanja Modal sebagai Variabel Intervening. Jurnal Prestasi, 9(1). 